Scientific Bulletin, № 2, 2021, pages 137-141

Fidan Ilham Guliyeva, klinikpsixoloqfidan@mail.ru

Western Caspian University

DOI: doi.org/10.54414/cipo5239

e-ISSN: $2789-4614$

\title{
ABSTRACT
}

\section{ANALYSIS OF THE PSYCHOLOGICAL CONTENT OF THECONCEPT OF DEPRESSION}

The article discusses the phenomenology, diagnosis and general characteristics of depression. It is also worth considering that depression is different from normal mood changes and problems in everyday life, from short-term emotional reactions, it can be a serious health problem, especially if it continues. life

Keywords: depression, main symptoms, physical and psychologicalhealth, quality of

\section{DEPRESSIYYA ANLAYIŞININ PSIXOLOJİ MOZMUNUNUN TəHLILI}

\section{XÜLASə}

Məqalədə depressiyanın fenomenologiyasından, diaqnostikasından vəümumi xüsusiyyətlərindən bəhs edilmişdir. Həmçinin depressiyanın normal əhval-ruhiyyə dəyişikliklərindən və gündəlik həyatda baş verən problemlərə qarş1, qisa müddətli emosional reaksiyalardan fərqli olduğuna, xüsusilə də davam edərsə, ciddi bir sağlamlıq problemi ola biləcəyinə nəzər yetirilmişdir.

Açar sözlər: depressiya, əsas əlamətlər, fiziki və psixoloji sağlamlıq, həyat keyfiyyəti

\section{АНАЛИЗ ПСИХОЛОГИЧЕСКОГО СОДЕРЖАНИЯПОНЯТИЯ ДЕПРЕССИИ \\ РЕЗЮМЕ}

В статье рассматриваются феноменология, диагностика и общие особенности депрессии. Также было показано, что депрессия отличается от обычных перепадов настроения и краткосрочных эмоциональных реакций на проблемы в повседневной жизни и может быть серьезной проблемой для здоровья, особенно, если она не проходит.

Ключевые слова: депрессия, основные симптомы, физическое и психологическое здоровье, качество жизни 
Depressiya hazırda qazanılmış immun çatışmazlığı sindromu və ya xərçəng xəstəliyi ilə müqayisədə daha geniş yayılıb. Hazırda dünyada demək olar ki, hər 6 nəfərdən biri depressiya, narahatlıq və ya hər ikisindən əziyyət çəkir. Ohval pozğunluqlarının geniş yayılmasına baxmayaraq, onların nevroloji fonu və patogenezi mübahisəlidir. Depressiya - yuxusuzluq, yüksək halsızlıq, gərəksizlik hissi, intihara dair fikirlər, iştahanın azalması, psixomotor tormozlanma və ya həyəcan, həmçinin müxtəlif somatik simptom və şikayətlərlə müşayiət olunan, əhval-ruhiyyənin enməsi ilə səciyyələnən psixi pozuntudur. Tibbi kontekstdə depressiya, bu terminin adi (bayağı) anlamından - ümidsizlik, əzginlik və kədər halından - fərqlənir və tibbi yardımın göstərilməsini tələb edir.

$\mathrm{Bu}$ s1x görülən ruhsal xəstəliyin səbəbləri qədim zamanlardan bəri araşdırılmışdır. Hippokrat, depressiyanı qara ödün miqdarındakı artmaya bağlayaraq, eyni zamanda depresiyyanın etimologiyası ilə bağlı açıqlamaların ilk örnəklərindən birini ortaya qoymuş hesab olunan şəxslərdən biridir. Bir çox insan depressiyaya sadəcə şəxsin başına gələn mənfi hadisələrin yol açtığını düşünür. Halbuki, depressiya tək bir səbəbə bağlı bir xəstəlik deyildir. Yaşanan hadisələr, şəxsi keyfiyyətlər və bunlara paralel olaraq depressiyaya tutulmanı asanlaşdıran beyindəki kimyəvi dəyişikliklər bu gün depressiyaya səbəb ola biləcəklərə inanılan 3 əsas göstərici hesab olunur [1, s. 40].

Depressiya sosial, psixoloji və bioloji amillərin kompleks qarşılıqlı təsiri nəticəsində inkişaf edir. Bir növ mənfi hadisə (iş itkisi, itkin düşmə, travma) yaşamış insanların depressiyaya düşmə ehtimalı daha yüksəkdir. Depressiya öz növbəsində stresi daha da artıra bilər, normal fəaliyyətini poza bilər, bundan əziyyət çəkən insanın həyat vəziyyətini pisləşdirə və daha da ağır depressiyaya səbəb ola bilər.

Depressiya necə yaranır? «İnsanın fiziki və psixoloji sağlamlığı üçün onun ətrafda baş verən hadisələr üzərində hakim olması və onları müstəqil şəkildə nəzarətdə saxlamaq imkanı olmalıdır. İnsan öz həyatını dəyişdirməyə qadir deyilsə və bütün baş verənlər onun iradəsindən asılı deyilsə, ilk növbədə həmin şəxsin varlığına köməksizlik hissi hakim kəsilir və o, vəziyyəti dəyişmək üçün heç bir fəaliyyət göstərmir. Bütün bunlar həmin şəxsdə depressiv vəziyyətin başlanması deməkdir. Bu xəstəlikdə pasiyentin əhval-ruhiyyəsi sanki ətraf mühitdən asılılıq təşkil edir. Đsasən axşam saatlarında daha çox depressiya əlamətləri müşahidə edilir. Bu şəxslərdə özünə qarşı inamsızlıq, kədər, utanc, hətta günah hissi də müşahidə edilməkdədir [2, s.17]. Enerji imkanlarının azalması, iş qabiliyyətinin tükənməsi, tez-tez yorulma halları fonunda motivasiya sferasında da əsaslı dəyişikliklər müşahidə edilir. Bir obyektdə uzun müddətli diqqətin cəmlənə bilməməsi, qərar qəbul etməkdə çətinliklər, yuxusuzluq kimi simptomlar özünü qabarıq şəkildə biruzə verir və bu simptomlar motivlərin ierarxiyasında müvafiq təzahürlər meydana çıxarır. Emosional sferada baş verən bu tip düşkünlük, laqeydlik halları suisidal meylin yaranmasina da səbəb ola bilər. 
Depressiyaya səbəb olabiləcək yaşam hadisələri arasında;

- Ev dəyişdirmə

- işini itirmək

- Sevilən birinin itkisi ilə üz-üzə qalmaq

- Önəm kəsb edən bir münasibətin sonlanması

- Ailə vəya önəmli olan digər insanlarla mübahisələr

- İşdən məmnuniyyətsizlik

- Fiziki və yaxud ruhsal anlamda tükənmə

- Tonhaliq

- Doğum

- Uşaqların evdən ayrılması

- Yaşın irəliləməsi yer alır.

Bütün bu yuxarıda sadalananların ortaq özəllikləri şəxsdə itirmə hissini yaratmalarıdır. Bəzən müsbət görülən yaşam hadisələri belə bu itirmə hissini tətikləyə bilər. Misal olaraq; universitetdən məzun olan biri, bu hadisədən sonra depressiyaya düşə bilər. Oslində baş verən hadisə müsbət bir hal kimi görünsədə, eyni zamanda bu hadisə həmin şəxsin birdə tələbə olmayacağı anlamınıda verir. $\mathrm{Bu}$, ətrafda baş verən hadisələrin şəxs üçün nə dərəcədə əhəmiyyət kəsb etməsindən, onun şəxsi xüsusiyyətlərindən və dolayısı ilə idraki özəlliklərindən asılı ola bilər. Məsələn; məsuliyyətə önəm verən obsessiv xüsusiyyətlərə malik şəxs üçün verdiyi bir sözü tutmamaq travmatik bir məna kəsb etdiyi halda, məsuliyyət hissi inkişaf etməmiş bir antisosial şəxsdə bu hadisə heç bir sıxıntı yaratmayacaqdır. Depressiyanın bioloji təsiredicilərinə misal olaraq aşağıdakıları sadalaya bilərik;

$>$ Alkoqol qəbulu

$>$ Dərman istifadəsi

$>$ Mövsümi dəyişikliklər

$>$ Somatik xəstəliklər

$>$ Yaşın irəliləməsi və s.

Klinik depressiyya aşağıdakı sahələrə təsir göstərə bilər:

- Yuxu

- İştah

- Düşünmə prosesi

- Gələcəklə bağli ümidlər

- Oylənca

- Cinsəllik

- İşləmə bacarığ 1

- Ailə fərdləri və dostlarla olan münasibətlər

- Şəxsin yaşama istəyi

- Daxili güc (enerji səviyyəsi) 
Depressiya ən geniş yayılmış psixi pozuntudur. Depressiya, şəxsin yaşına, işinə, cinsiyyətinə, gəlirinə, hansı milliyyətdən yaxud hansı dindən olmasına baxmayaraq hər kəsdə üzə çıxa bilər. Depressiya qadınlarda, kişilərdən iki qat daha çox görülür. İlk depressiya dönəmi daha çox 25-44 yaşları arasında ortaya çıxır. Xəstələrin təxmini yarısında ilk depressiya dönəmi 40 yaşından öncə meydana çıxır, lakin qeyd olunmalıdır ki, həm uşaqlıq və yeniyetməlik dönəmlərində, həm də yaşlılıq dönəmində də ilk dəfə ortaya çıxa bilər. Boşanmış yaxud da ayrı yaşayan cütlüklərdə görülmə sıxlığı daha yüksəkdir. Altda yatan səbəb bilinməsə də, depressiyanın yaradıcı şəxslərdə daha çox təsadüf olunması müşahidə olunur. Şuman, Mozart, Çaykovski, Van Gog, Abraham Linkoln, Ruzvelt, Çörçil və s. Müxtəlif mənbələrə əsasən, böyük yaş dövrünə aid olan əhalinin həyatı boyu depressiyaya "yoluxması", kişilər arasında 2,5 \%-dən 10\%-dək, qadınlar arasında isə 5\%-dən 20\%-dək dəyişir. Depressiya, bu pozuntudan əziyyət çəkən qohumları olan şəxslərdə 1.5-3 dəfə daha çox təsadüf olunur. Eyni zamanda bütün dünyada depressiyanın yayılma səviyyəsinin yüksəlməsi və bu məfhumun gəncləşməsi tendensiyası qeydə al1nır. Depressiyanın yayılma səviyyəsi uşaqlar arasında $2 \%$, yeniyetmələr arasında 4-8\% təşkil edir. Depressiv pozuntu istənilən yaş dövründə başlaya bilər. Lakin bununla yanaşı o daha çox 25-30 yaş arası başlayır [4, s. 8].

Depressiya nəticəsində, şəxsin yaşamının bir çox sahələrində problemlər ortaya çıxa bilər. Bunlardan bəzilərini sadalasaq;

$>$ İş, məktəb yaxud da ev yaşamında problemlər

$>$ Ailəvi problemlər

$>$ Qəzalar (diqqət dağılmasına bağlı)

$>$ Somatik xəstəliklər

$>$ Siqaret, alkoqol və maddə bağımlılığı (həm səbəb, həm nəticə ola bilər)

$>$ İntihar [3, s.17].

Depressiyası olan şəxslərdə ümümi fəaliyyət aktları azalmış olsada, əksinə özünügünahlandırma və özünütənqid artmağa başlayır. Məhz bunlar, şəxsin özünü daha da kədərli hiss etməsinə yol açar. Bunlara paralel olaraq, depressiyalı şəxslərin əksəriyyətində görülən diqqət əksikliyi və fokuslanmaqda olan çətinliklər, şəxsin əksiklikləri mövzu olduğu zaman daha da artmağa başlayır. İşinizi, etməniz gərəkdiyini düşündüyünüz şəkildə etmədiyiniz və ya insanlara yük olduğunuz düşündüyünüz üçün özünüzü günahlandırmış olursunuz. İşlər mənfiyə doğru getdiyi zaman, həmin anda da bunun sizin səhviniz ucbatından olduğunu düşünürsünüz.

Depressiyadakı bir digər önəmli məsələlərdən biri də şəxsin özünə olan güvəninin və inancının azalmasıdır. Bu güvən azalması, uğur yaxud sevilmə baxımından şəxsin özünə qoyduğu yüksək standartlar və aşırı şəkildə olan gözləntilərdən qaynaqlana bilər. Məsələn; mükəmməl bir ev xanımı, ana, yaxud heç yorulmadan, tükənmədən, yanılmadan bir həkim olmanızın gərəkliliyinə inana bilərsiniz. 
Psixi və Davranış Pozuntularının Beynəlxalq Təsnifatına (XBT10) uyğun şəkildə depressiv pozuntu diaqnozunun qoyulması üçün əlamətlər 2 həftədən az olmayaraq müşahidə edilməlidir. Anamnezdə maniakal və ya hipomaniakal epizodlar olmamalıdır. Simptomlar psixoaktiv maddələrin qəbulu və ya istənilən orqanik psixi xəstəlik ilə əlaqəli olmamalıdır.

Depressiyanın əsas əlamətləri:

- Pasiyent üçün qeyri-normal hesab edilən səviyyəyədək uzun müddət əhvalın enməsi

- Adətən pasiyent üçün xoş olan məşğuliyyətə aydın formada marağın və alınan zövqün azalması

- Demək olar ki, hər gün müşahidə edilən yorulma və güc tükənməsi.

Depressiyanın əlavə əlamətləri:

- Özünəinamın və özünüqiymətləndirmə hissinin enməsi

- Qeyri-adekvat günahkarlıq hissi və səbəbsiz özünütənqid

- Təkrarlanan ölüm və ya özünəqəsd fikirləri və ya intihar davranış1

- Düşünmə və fikir cəmləmə qabiliyyətinin azalması

- Tormozlanma və ya həyəcanla müşayiət olunan psixomotor fəallığın pozulması (subyektiv və ya obyektiv)

- İstənilən növ yuxu pozuntusu (yuxusuzluq və ya yuxuculluqsüstlük)

- Çəki dəyişkənliyi ilə müşayiət olunan iştahanın dəyişməsi (artmas1 və ya azalmas1)

İfadə səviyyəsindən asılı olaraq əlamətlər fərqlənir:

Yüngül depressiya epizodu - əsas əlamətlərdən ən azı 2-si və əlavə əlamətlər müşahidə olunur (ümumi sayda 4-dən az olmayaraq)

Orta dərəcəli depressiya epizodu - əsas əlamətlərdən ən azı 2-si və əlavə əlamətlər müşahidə olunur (ümumi sayda 6-dan az olmayaraq)

Psixotik əlamətlərsiz ağır depressiya epizodu - əsas əlamətlərin hər üçü və əlavə əlamətlər müşahidə olunur (ümumi sayda 8-dən az olmayaraq)

Psixotik əlamətlərlə ağır depressiya epizodu - sayıqlama, qarabasma və ya depressiv stupor zamanı diaqnozlaşdırılmalıdır. Bu halda özünügünahlandırma sayıqlamaları, ipoxondrik, nihilistik və persikutor məzmunlu münasibət daha xarakterik mövzulardandır [4, s. 11].

\section{Odəbiyyat:}

1. Prof. Dr. M. Hakan Türkçapar. Depresyon . İstanbul: 2018, 569 s.

2. Prof. Dr. Ertuğrul Köroğlu. Depresyon. Ankara: 2015, 240 s.

3. Rabia Kürümlüoğlugil. Depresyonla başetmede düşünce yöntemi. Antalya; 2019, $111 \mathrm{~s}$.

4. https://www.isim.az/upload/File/reports/21_Depressiya.pdf 